Scottish Popular Politics 



\title{
Scottish Popular Politics
}

\author{
From Radicalism to Labour
}

W. Hamish Fraser

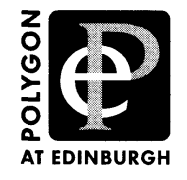




\section{To Ian MacDougall}

without whose work many of the records of working people's activities would have disappeared.

(C) W. Hamish Fraser, 2000

Transferred to Digital Print 2010

Polygon at Edinburgh

An imprint of Edinburgh University Press Ltd

22 George Square, Edinburgh

Typeset in Garamond

By Bibliocraft Ltd, and

Printed and bound in Great Britain by

CPI Antony Rowe, Chippenham and Eastbourne

A CIP record for this book is available from the British Library

ISBN 1902930118 (paperback)

ISBN 9781474496896 (EPDF)

The right of W. Hamish Fraser

to be identified as author of this

work has been asserted in accordance

with the Copyright, Designs and Patents Act 1988. 